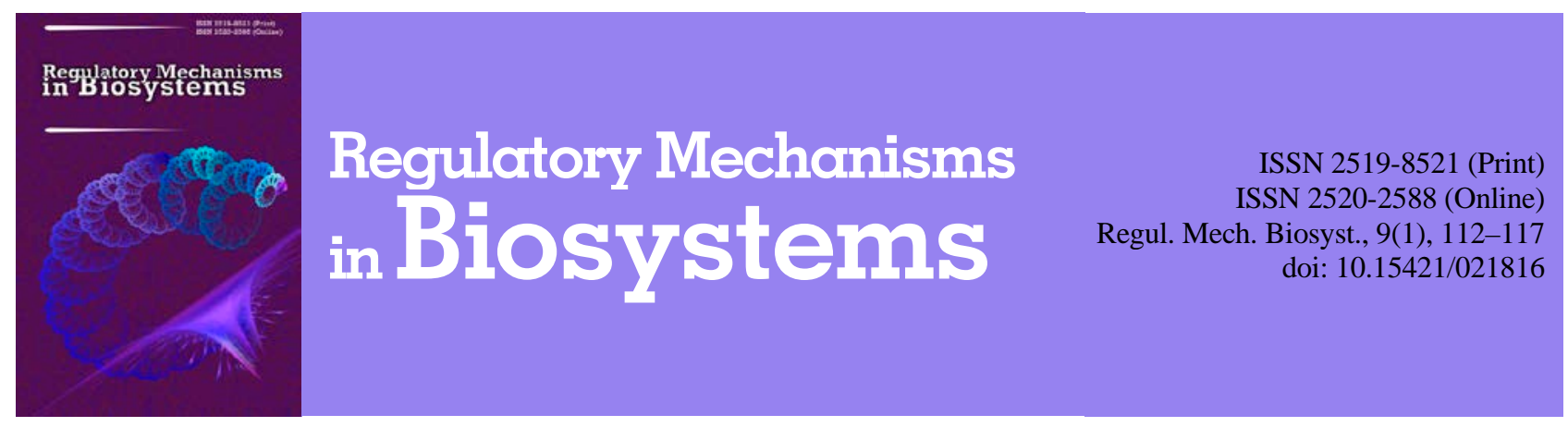

\title{
Clostridium perfringens in foods and fish
}

\author{
A. D. J. Cortés-Sánchez \\ Consejo Nacional de Ciencia y Tecnología (CONACYT), Centro de Investigaciones Biológicas del Noroeste, Unidad Nayarit \\ (UNCIBNOR+).Tepic, Nayarit, México
}

Article info

Received 14.02.2018

Received in revised form 27.02.2018

Accepted 28.02.2018

Consejo Nacional de Ciencia y Tecnología (CONACYT),

Centro de Investigaciones

Biológicas del Noroeste,

Unidad Nayarit (UNCIBNOR+),

Calle Dos No. 23, Cd. del

Conocimiento, Av. Emilio

M. González, Cd. Industrial,

C.P. 63173, Tepic, Nayarit,

México.

E-mail:

alecortes_1@hotmail.com
Cortés-Sánchez, A. D. J. (2018). Clostridium perfringens in foods and fish. Regulatory Mechanisms in Biosystems, 9(1), 112-117. doi: 10.15421/021816

Foodborne diseases are considered an important public health problem at a global level due to their levels of incidence and mortality as well as their negative consequences in economic and social aspects. Foodborne diseases are defined as those that are generated by the ingestion of food and water contaminated by chemical or biological agents commonly affecting health at the level of the gastrointestinal system. Among the risks and dangers to health from food are the diseases caused by Clostridium perfringens, a common bacterium which inhabits water, soil, vegetables, fish, the gastrointestinal system of human and animals and of course foods. The importance of this bacterium in health and food lies both in its cosmopolitan distribution, ability to generate heat-resistant spores and food poisoning, which makes control and prevention actions indispensable along the food chain. This article presents a general description of foodborne diseases, including those caused by consumption of food, such as fish, derived from contamination by C. perfringens; likewise, the actions and recommendations undertaken around the world for the prevention and control of these diseases are shown, including aspects related to the antimicrobial resistance phenomenon and its impact on public health.

Keywords: foodborne diseases; food safety; microorganisms; gastrointestinal symptoms

\section{Foodborne diseases generalities}

Foodborne diseases (FD) are those caused by the ingestion of food and water contaminated by microorganisms or chemical substances, the most common clinical manifestation being the appearance of gastrointestinal symptoms (WHO, 2018). These diseases are considered an important public health problem at a global level due to their incidence and mortality together with the negative economic and social repercussions (Palomino \& Gonzalez, 2014; Lorenzo \& Gálvez, 2015).

Estimates from the World Health Organization (WHO) indicate that annually around the world FD cause 420,000 deaths, of which one third are of children; while for the Americas region they indicate that around 77 million people fall ill and more than 9,000 die from these diseases (WHO, 2018a). In the United States alone, it is estimated that around 76 million people suffer from FD, 325,000 are hospitalized and 5,000 die each year, implying high health services costs (Olea et al., 2012). Factors such as the mobility of populations, growing urbanizetion, new forms and industries of production and sale of food, changes in eating habits, the globalization of the market and the lack of knowledge or perception of risk to health by all those involved in the chain of food production and service have contributed to a higher rate of contamination and incidence of diseases in consumers (Olea et al., 2012; Palomino \& Gonzalez, 2014; Lorenzo \& Gálvez, 2015).

Food due to its composition in water and nutrients is a favorable environment for microbial growth and in turn constitutes a vehicle for the transport of different diseases. Furthermore, if warm environmental conditions are present, microbial growth can be further favored by unhygienic practices during the handling of products; pathogenic microorganisms can be transferred to the surface of food from many sources (soil, water, insects, food handlers), which generates health risks for the consumer (Barbosa \& Bermudez, 2010). Food contamination can be widespread and varied, with approximately 250 causal agents of diseases described; these contaminants can be of physical, chemical and biological origin, among which are included bacteria, viruses, fungi, parasites, prions, toxins and metals that can compromise the consumer's health; where contamination by biological agents (bacteria, fungi, viruses and parasites) represents the highest incidence and risk to health (Barreto et al., 2010; Olea et al., 2012; PAHO, 2016). Among the bacteria generally involved in the production of diseases through food are Staphylococcus aureus, Listeria monocytogenes, Escherichia coli, Clostridium perfringens, Campylobacter jejuni, Salmonella spp., Shigella spp., among others (USDA, 2013).

This article presents a general description of foodborne diseases, including those caused by food consumption, such as fish deriving from contamination by microbial agents such as $C$. perfringens; likewise, the actions and recommendations for the prevention and control of these diseases are shown; in addition to showing the incidence of the phenolmenon of antimicrobial resistance by this pathogenic bacterium.

\section{The genus Clostridium}

The genus Clostridium is formed by around 150 species, which are both phylogenetically and phenotypically heterogeneous. Some species are of importance in various industrial areas, such as C. acetobutylicum, C. beijerinckii and C. butirycum, since they produce organic solvents (Castaño, 2008), C. pasteurianum are involved in deterioration in storage stability of food and juices that undergo inadequate thermal processes (Feng et al., 2010) while species such as C. botulinum, $C$. perfringens, $C$. tetani and $C$. difficile are of clinical importance and must be considered pathogenic to food, giving rise to diseases by action of extracellular toxins (Rhodehamel \& Harmon, 2001; Morris \& Fernandez, 2008; El-Shorbagy et al., 2012; García et al., 2016). The bacteria of 
the genus Clostridium, are characterized by having a vegetative form in the form of bacilli. They are gram positive, anaerobic, do not form pili and fimbriae, have peritrichous flagella except for $C$. perfringens and form spores and toxins. They are located generally in nature and commonly as a constituent part in the gastrointestinal system of animals, spreading through food, thus generating food intoxication (Romero, 2007; Elika, 2013). The species associated with diverse pathologies in humans, including the alimentary toxi infections (C. difficile, C. novyi, C. septicum, C. histolyticum, C. sordelli, C. fallax, C. botulinum and $C$. perfringens); the toxins of the latter affect the nervous and gastrointestinal system respectively (Romero, 2007; Elika, 2013; OPS, 2016).

\section{Clostridium perfringens}

C. perfringens is a bacterium belonging to the family Bacillaceae in the form of a bacillus measuring: $4-8 \mu \mathrm{m} \times 0.3-1.5 \mu \mathrm{m}$, Gram positive, capped, non-mobile, sporulated, it is relatively aerotolerant, catalase negative, fermented carbohydrates (glucose, lactose, sucrose, fructose, maltose and galactose) with production of acid and carbon dioxide, produce $\mathrm{H}_{2} \mathrm{~S}$ and hydrogen, its optimal growth temperature is $37-45^{\circ} \mathrm{C}$ and it tolerates $\mathrm{NaCl}$ concentrations of $2 \%$, is anaerobic but able to grow at values of Eh of $+350 \mathrm{mV}$ and reduce its environment to less than $-400 \mathrm{mV}$, it has a cosmopolitan distribution in the environment mainly in soil, wastewater, spices, vegetables, raw foods, processed foods and in the gastrointestinal system of man and animals (Pascual \& Calderón, 2000; Morris \& Fernández, 2008; Massoc, 2008; Santos \& Heredia, 2011; Gamboa et al., 2011; El-Shorbagy et al., 2012; CDC, 2017). Being a microorganism sporulated under unfavorable conditions or growth stress in its vegetative forms, it generates heat-resistant spores as forms of survival, whose process is linked to the production of toxins (Pascual \& Calderón, 2000; Morris \& Fernandez, 2008; Massoc, 2008; El-Shorbagy et al., 2012). A high correlation has been established between the ability of $C$. perfringens strains to produce toxins and generate food poisoning and conditions such as necrotic enteritis and gas gangrene (Rhodehamel \& Harmon, 2001; El-Shorbagy et al., 2012). The ability of $C$. perfringens to generate spores by sulfite-reducing clostridia, being inhabitants of the gastrointestinal system of mammals and resistant to different conditions of environmental stress, makes them useful as indicators of fecal contamination of water for human use and consumption which can put health at risk (Rios et al., 2017).

Food poisoning by $C$. perfringens tends to be self-limiting, symptoms appearing suddenly such as watery diarrhea, severe abdominal pain and cramping 8 to 16 hours after ingestion lasting approximately 24 hours. The vast majority of outbreaks of disease are related to inadequate handling, preparation and preservation of food, such as temperature control, especially in meat and meat products (Perdomo \& Melendez, 2004; Massoc, 2008; CDC, 2017). It is estimated that $C$. perfringens is capable of generating toxinfection through ingestion in foods with inocula above $10^{5}$ to $10^{8} \mathrm{CFU} / \mathrm{g}$ (Pascual \& Calderón, 2000; Santos \& Heredia, 2011; PAHO, 2016). The population in general is susceptible to poisoning by this pathogen but children under 5 years of age, older adults, pregnant women and people with weakened immune systems are at higher risk of $C$. perfringens infection and experience more severe symptoms (CDC, 2017).

The virulence factors attributable to $C$. perfringens include the capacity to generate different toxins. Among those one usually finds the toxin alpha $(\alpha)$, beta $(\beta)$, epsilon $(\varepsilon)$ and iota (1) that are used for the bacterial classification of the species into five toxinotypes from $\mathrm{A}$ to $\mathrm{E}$ according to the toxins produced where the type A produces $(\alpha), B$ produces $(\alpha),(\beta)$ and $(\varepsilon), C$ produces $(\alpha)$ and $(\beta), D$ produces $(\alpha)$ and $(\varepsilon)$ and E produces $(\alpha)$ e (1) (Morris \& Fernandez, 2008; Gamboa et al., 2011; El-Shorbagy et al., 2012). This microorganism also generates different enzymes hydrolytics: lecithinases, hemolysins, hyaluronidases, collagenases, DNAase and amylases (Santos \& Heredia, 2011). It also presents the synthesis of other protein toxins that also contribute to virulence but are not considered for their classification, such as CPE enterotoxin encoded by the cpe gene responsible for diarrhea in humans and animals, the NetB associated with necrotic enteritis in birds and $\beta_{2}$ toxin, related to enteritis cases (Morris \& Fernandez, 2008; Gamboa et al., 2011). Foodborne diseases that have C. perfringens as a causative agent are commonly related to type A strains, while necrotic enteritis is caused by type C and some type A strains (Santos \& Heredia, 2011). According to estimates from the Centers for Disease Control and Prevention of the United States of America (CDC), approximately one million cases of foodborne diseases caused by $C$. perfringens are recorded annually, it being one of the most common causative agents of food poisoning (CDC, 2017). Reporting food poisoning by C. perfringens is not mandatory in this country. However, the centers for disease control and prevention estimate 250,000 cases per year due to food poisoning due to C. perfringens type A (Santos \& Heredia, 2011).

\section{C. perfringens and fish}

Fish is considered an important source of food due to its easy digestibility, high nutritional value due to its composition of water, proteins, lipids, vitamins, minerals and carbohydrates, besides representing a source of economic and living income for millions of people around of the world (FAO, 1998, 2016; Sheyin \& Solomon, 2017). However, these same characteristics make this food a highly susceptible source of deterioration and decomposition by enzymes of the fish itself (autolysis) and microorganisms, converting them into a vehicle of diseases when consumed (Avdalov, 2009). The microbiote present in fish is related to various factors such as: the nature of the water, temperature, food, season of year from which they are extracted, among others. Human activities have had a detrimental effect on water, so there may be a risk of contamination with pathogenic microorganisms from it, as well as by those activities involved in capture, cultivation (aquaculture), processing and conservation actions, such as for example the use of poor quality water, poor hygiene practices in handling, while fish processing facilities which are contaminated can be contaminated by chemical or biological agents (García \& Calvario, 2008; Avdalov, 2009; Sheyin \& Solomon, 2017). C. perfringens being a cosmopolitan microorganism can be located in diverse environments such as the soil, aquatic ecosystems, gastrointestinal system of animals and fish, as well as raw and processed foods (Matches et al., 1974; Kimura, 1996; Santos \& Heredia, 2011; Sheyin \& Solomon, 2017). This microorganism has been implicated in outbreaks of food-borne diseases that are related to the consumption of meat and derivatives, including fish; in the United States of North America in the period from 1998 to 2008, 2468 cases of foodborne diseases were reported, in which there were 461 cases of this pathogen being identified as the causative agent (Kimura, 1996; ElShorbagy et al., 2012; Painter et al., 2013; CDC, 2017). The cases of foodborne diseases that have $C$. perfringens as a producing agent are related to inadequate storage, processing and food service operations, preferably in places that concentrate large groups of people such as hospitals, school canteens, prisons and old people's homes, or in events with food service (Kimura, 1996; El-Shorbagy et al., 2012; CDC, 2017). The ubiquitous nature of this microorganism and its spores make it a frequent problem and challenge for the food industry and establishments that produce large amounts of food (Santos \& Heredia, 2009).

\section{Isolation of $C$. perfringens in foods and fish}

For the isolation and detection of $C$. perfringens in food, there are several standardized methods in the scientific collection, such as the one developed by the International Organization for Standardization (ISO) ISO 7937:2004 for the colony count of $C$. perfringens (Fig. 1), the method reported by Rhodehamel \& Stanley (2001), presented in the Bacteriological Analytical Manual (BAM) of the Food and Drug Administration (FDA) of the United States of America (Fig. 2) is also the method reported by McNamara \& Lattuada, (1998) presented in the microbiology laboratory guide of the United States Department of Agriculture (USDA) and the Food Safety and Inspection Service (FSIS) (Fig. 3). All these methods present some similarities in conditions and culture media used for isolation, quantification, and biochemical confirmation for the emission of results to $C$. perfringens. It should be noted that prior to the microbiological analysis, a core point of the method to be developed is actions that involve the collection and transport of the 
sample, so it is recommended that the sample once collected for analysis should be transported immediately to the laboratory at temperatures $0-10{ }^{\circ} \mathrm{C}$. The samples collected for analysis that cannot be analyzed immediately require special treatment; being sensitive, $C$. perfringens may lose viability in prolonged periods of refrigeration and freezing, so they should be treated with a buffered glycerin saline solution, stored or sent frozen to the laboratory (McNamara \& Lattuada, 1998; Rhodehamel \& Harmon, 2001).

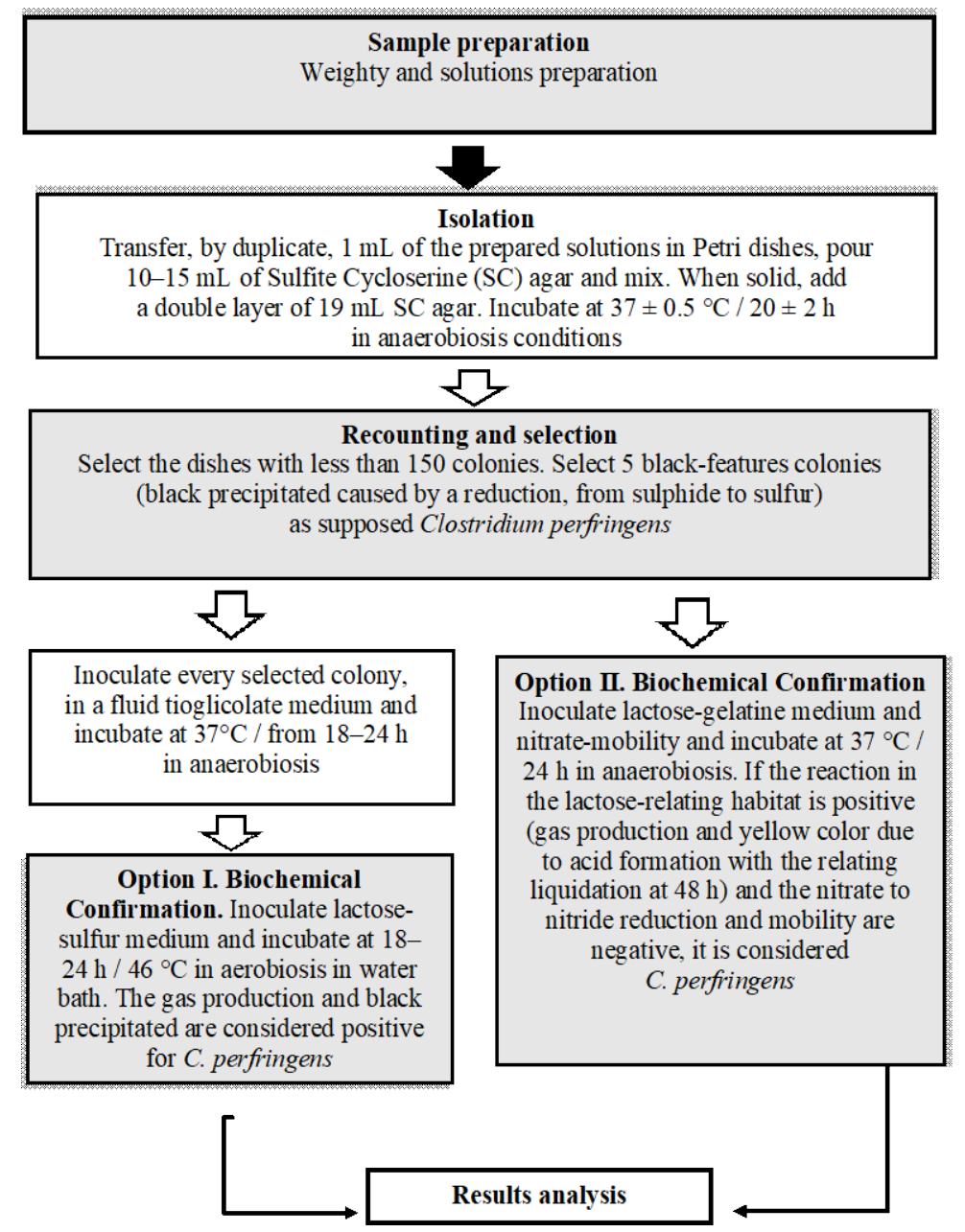

Fig. 1. Method for plate count of Clostridium perfringens in food samples (ISO 7937: 2004; ANMAT, 2013)

\section{Control and prevention of foodborne diseases}

Food poisoning by $C$. perfringens is commonly due to inadequate handling of the temperature in the processing, maintenance or reheating of food, as well as its preparation in advance of consumption (Santos \& Heredia, 2011). Low levels of $C$. perfringens occur in raw meats, poultry, soups, dehydrated sauces, raw vegetables or spices during food preparation; this coupled with the heat resistance and oxygen that can be decreased during cooking processes favors the growth of bacteria; thus spores that survive cooking can germinate and grow rapidly in foods that do not undergo adequate refrigeration processes after the cooking treatment (Rhodehamel \& Harmon, 2001; Santos \& Heredia, 2011). On the other hand, C. perfringens generally loses its viability when food is frozen or kept in prolonged refrigeration; for analytical issues in the laboratory this characteristic can hinder isolation and detection in food as well as establish the causes of an outbreak of food poisoning (Rhodehamel \& Harmon, 2001). The actions focused on the control and prevention of diseases by this pathogen in food are involved in the stages of production and storage of food in which the cooling of food must be below $10^{\circ} \mathrm{C}$, for two or three hours, and the preservation of hot foods above $60^{\circ} \mathrm{C}$ prior to consumption. In the case of reheating cold or refrigerated food, these should reach a minimum internal temperature of $75{ }^{\circ} \mathrm{C}$. Likewise, cross contamination with utensils and contaminated surfaces must be prevented (OPS, 2016).

Throughout the food chain, from primary production through industry to household manipulation prior to consumption, strategies and procedures have been developed, recommended and implemented in a global manner that contribute to minimize the health risks of the consumer, some of these are: good agricultural practices (GAP), good livestock or livestock practices, good fishing practices and aquaculture that contribute to reducing the contamination of food with soil and fecal animal matter, thus minimizing the bacterial load on the subject premium, as well as the application of good manufacturing practices (GMP) appropriate hygienic practices in the handling and processing, development and implementation of control systems based on Hazard Analysis and Critical Points (HACCP), compliance with the microbiological criteria of raw materials in order to reduce or prevent pollution by diverse microorganisms including strains of the genus Clostridium and finally, for home consumption, the World Health Organization (WHO) has developed informative handbooks aimed at the general population on hygiene conditions in the storage, handling and preparation of food in a healthy and safe way (WHO, 2007; García \& Calvario, 2008; Ramírez \& Ishihara, 2008; Avdalov, 2009; FAO, 2009; Elika, 2013; ANMAT, 2013; Gómez et al., 2015). On the other hand, other measures of control and prevention of contamination and deterioration of food include the use of chemical preservatives; in the food industry this is considered an alternative and common practice to reduce the pathogenic and deteriorating microbial population thus avoiding risks for the health and prolonging the life of the products; In different investigations around the world, effective results have been reported when combined with other barrier technologies against $C$. prefringens (Santos \& Heredia, 2011).

At the international level, there are different limits or microbiological specifications established for the sanitary quality of various pro- 
cesssed foods which are susceptible to contamination with Clostridium spp., Mexico has the official Mexican standard NOM-130-SSA1-1995 focused on packaged foods in hermetically sealed containers and subjected to heat treatment; indicating the sanitary dispositions and specifications in the microbiological character, such as the presence of anaerobic mesophiles that consist of bacteria of the genus Clostridium, among which are C. sporogenes, C. putrificans, C. hystoliticum, C. bifermentans, C. perfringens and $C$. botulinum of sanitary interest. For specific products such as formulas for infants, foods and non-alcoholic beverages for infants and young children, the Official Mexican Standard NOM-131-SSA1-2012, mentions the provisions, sanitary and nutritio- nal specifications, as well as the labeling and testing methods including in the microbiological specifications the anaerobic mesophilic microorganisms. With respect to sanitary quality and safe consumption of food, products and fishing services, the Official Mexican Standard NOM242-SSA1-2009 establishes sanitary specifications and test methods for fresh, chilled, frozen and processed fishery products, being the microbiological specification acceptable for C. botulinum, in fresh, chilled and frozen products as "absent" while the specification corresponding to the presence of sporulated anaerobic thermophiles and sporulated anaerobic mesophiles in commercially acceptable sterilized fishery products is "negative".

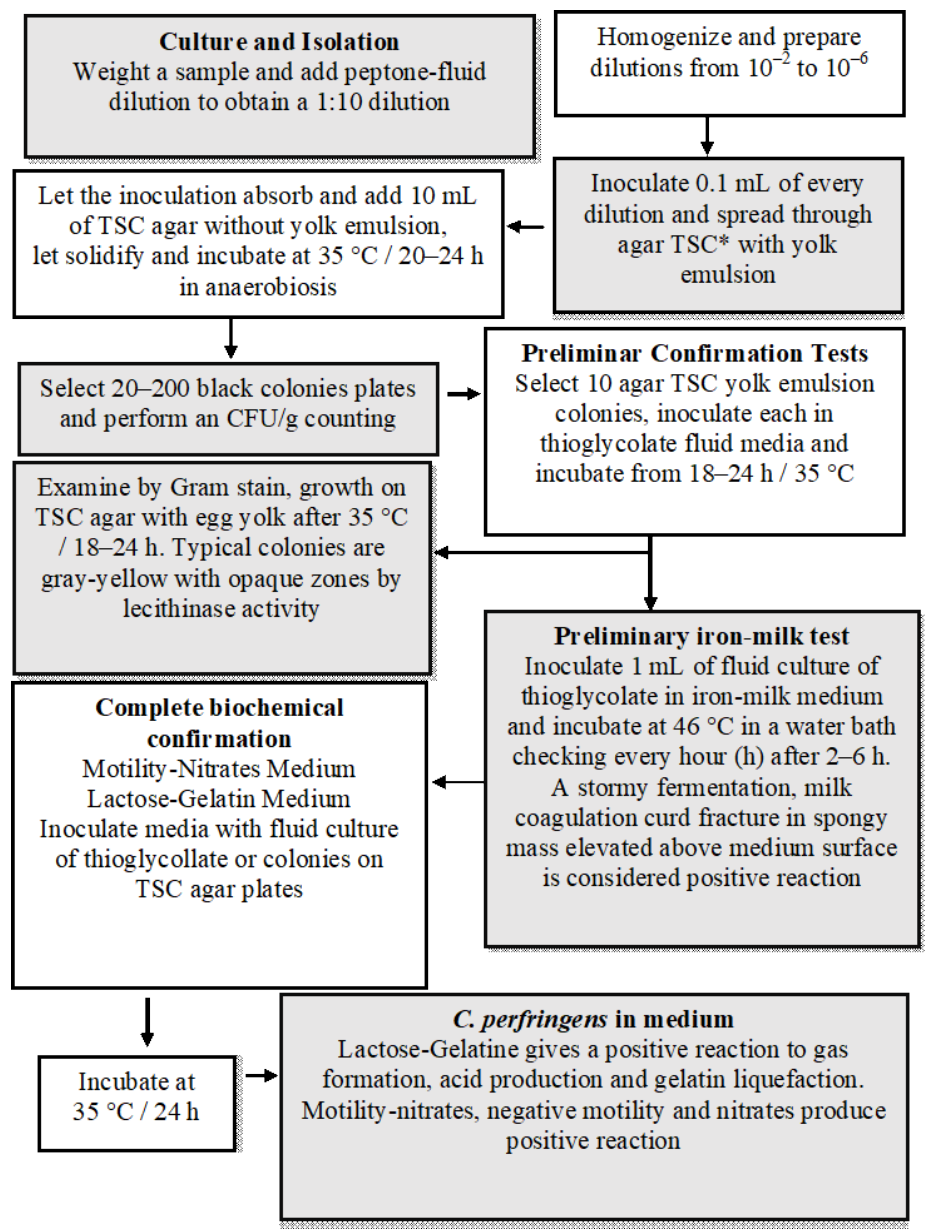

Fig. 2. Culture and isolation of $C$. perfringens from food (Rhodehamel \& Harmon, 2001): * - Tryptose-Sulphite-Cycloserine Agar (TSC)

On the other hand, the Official Mexican Standard NOM-251SSA1-2009, indicates the guidelines for hygiene practices for the process of food, beverages or food supplements; involving facilities, areas, equipment and utensils, services, storage, control of operations and raw materials, it also refers to the good practices of health and hygiene of the personnel, which also recommends the establishment of a system of hazard analysis and critical control points (HACCP) in order to prevent the generation of food that carries a risk to the health of the consumer. In Europe, on the part of the European Parliament and the Council of the European Union, Regulation (EC) No 178/2002 establishing the principles and general requirements of food legislation was established. European Food Safety Authority and procedures relating to safety to food safety are set; likewise by Commission Recommendation 2004/24/EC (DOCE 19/12/03) on the official control program for food products that recommends taking representative samples of spices at the level of import, production, packaging establishments, wholesale trade, establishments that use spices in food preparation and retail trade, in order to count $C$. perfringens with a microbiological limit of 100 $1000 \mathrm{CFU} / \mathrm{g}$ (Elika, 2013).

Several studies have been carried out around the world that have reported the isolation and profile of resistance to different antimicrobials by pathogenic microorganisms (C. perfringens, Salmonella spp., Listeria monocytogenes, Escherichia coli), among others which come from different natural environments such as soil, food, animals and human beings. These studies generate information for a more rational use of antibiotics in the areas of clinical, agriculture, livestock, fisheries and aquaculture, in addition to the detection of strains with antimicrobial resistance, which contributes to alert us about possible genetic transfer mechanisms in nature and generate strategies in control (Abraham et al., 2011; Gamboa et al., 2011; Granier et al., 2011; Puig et al., 2011; Slavic et al., 2011; Elhadi et al., 2014; Gharaibeh et al., 2014).

At global level, different actions have been developed and recommended in order to reduce the transmission of resistance to antimicrobials in the food chain and thus achieve food safety, among these actions are good manufacturing practices, sanitary control through of HACCP systems, good agricultural, livestock and aquaculture hygiene practices, in addition the Codex Alimentarius has issued guidelines such as CAC/GL 77-2011 for the risk analysis of antimicrobial resistance transmitted by food and the code of practice to minimize and contain antimicrobial resistance CAC/RCP 61-2005 (PAHO, 2015; FAO, 2017; FAO, 2018). The control of resistance to antimicrobials is a common task and, therefore, it is necessary that the participation of govern- 
ments around the world with the support of the scientific community generate actions focused on control and surveillance in the agricultural and clinical field by implementing surveillance and control policies and systems for the use of antimicrobials and the phenomenon of resistance, all in favor of the availability to the world population of food of good in nutritional quality and safety (Padgett et al., 2011; Gestal et al., 2014).

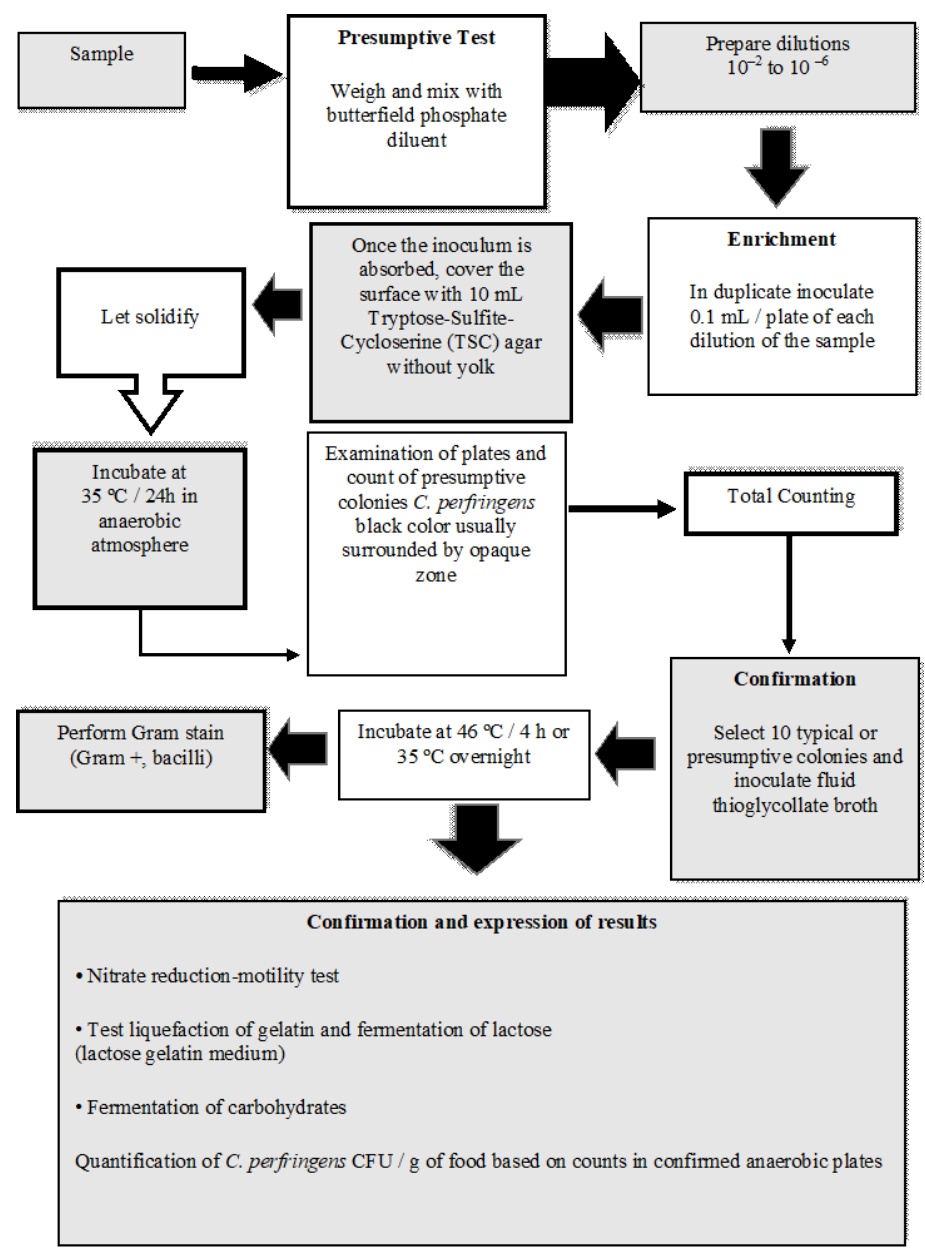

Fig. 3. Method of quantification of C. perfringens in foods (McNamara \& Lattuada, 1998)

\section{Conclusions}

Food is a priority need for human beings to achieve survival, growth, development and for fulfillment of their daily activities. However, during the production of food and throughout the food chain there can be microbial contaminations and these can be vehicles of biological hazards to health, giving rise to different diseases. Foodborne diseases are considered to be of great relevance worldwide in public health aspects due to their incidence and mortality rate, together with the fact that several years ago the appearance and increase of resistance to antimicrobials was reported. These diseases have different causal agents thus potentiating their importance, given the negative repercussions on health, economy and society.

C. perfringens is considered a danger of biological origin along the food chain and is described as a threat to human and animal health, since through the contamination of food and subsequent consumption it generates negative effects on health. This is complicated by reports worldwide on the isolation of strains resistant to different antimicrobials. Different strategies, procedures and actions have been developed and implemented around the world through international organizations, the food industry, government and academia to control and prevent food contamination by food pathogens such as $C$. perfringens, in an effort to guarantee the supply of safe food to the general population in all stages that go from its primary production through its processing and transformation until its conservation, manipulation and preparation prior to its consumption.

Satisfying the growing demand for safe and nutritious food globally still requires a great common effort from the food industry, governments, and academia, including the general population, through their awareness of the different risks and dangers to health from food, hand- ling and storage conditions for consumption in order to minimize the incidence of foodborne diseases and their impact on health.

\section{References}

Abraham, T. J. (2011). Food safety hazards related to emerging antibiotic resistant bacteria in cultured freshwater fishes of Kolkata, India. Advance Journal of Food Science and Technology, 3(1), 69-72.

An, S., \& Kj, S. (2017). Endo microbial fauna of Tilapia spp. (Oreochromis niloticus) found in a Flowing Canal at Eden Garden and Park Utako, Abuja. Journal of Fisheries and Livestock Production, 5(1), 214.

ANMAT. Administración Nacional de Medicamentos, Alimentos y Tecnología Médica. (2013). Red nacional de laboratorios oficiales de análisis de alimentos. Ministerio de salud. Presidencia de la nación Argentina. Análisis microbiológico de los alimentos. Metodología analítica oficial. Microorganismos Patógenos, 2, 141.

Avdalov, N. (2009). Manual de control de calidad y manipulación de productos pesqueros para pescadores y procesadores artesanales. Proyecto CFC/FAO/ INFOPESCA, FSCFT 23, "Mejoramiento de la Pesca Artesanal en Centro América, México y el Caribe”. INFOPESCA. Centro para los servicios de información y asesoramiento sobre la comercialización de los productos pesqueros de América Latina.

Barbosa-Cánovas, G., \& Bermúdez-Aguirre, D. (2010). Procesamiento no térmico de alimentos. Scientia Agropecuaria, 81-93.

Barreto Argilagos, G., Sedrés Cabrera, M., Rodríguez Torrens, H., \& Guevara Viera, G. (2010). Agentes bacterianos asociados a brotes de Enfermedades Trasmitidas por Alimentos (ETA) en Camagüey, Cuba, durante el período 2000-2008. REDVET. Revista Electronica de Veterinaria, 11(2).

Castaño, D. M. (2008). Produccion de solventes de alto valor agregado por cepas nativas de Clostridium spp. Revista Colombiana de Biotecnología, 10(1), 139-142. 
CDC. Centers for Disease Control and Prevention National, United States of America USA. Center for Emerging and Zoonotic Infectious Diseases (NCEZID). Division of Foodborne, Waterborne, and Environmental Diseases (DFWED) (2017). Clostridium perfringens.

Cota Rubio, E., Hurtado Ayala, L., Pérez Morales, E., \& Alcántara Jurado, L. (2014). Resistencia a antibióticos de cepas bacterianas aisladas de animales destinados al consumo humano. Revista Iberamericana de Ciencias, 1(1), 75-85.

Gamboa-Coronado, M. D. M., Mau-Inchaustegui, S., \& Rodríguez-Cavallini, E. (2010). Caracterización molecular y resistencia antimicrobiana de aislamientos de Clostridium perfringens de diferentes orígenes en Costa Rica. Revista de Biología Tropical, 59(4), 1479-1485.

Elhadi, N. (2014). Prevalence and antimicrobial resistance of Salmonella spp. in raw retail frozen imported freshwater fish to Eastern Province of Saudi Arabia. Asian Pacific Journal of Tropical Biomedicine, 4(3), 234-238.

Elika (2013). Clostridium. Fundación Vasca para la seguridad agroalimentaria.

El-Shorbagy, M. M., Reda Lamyaa, M., \& Mona, H. (2012). Prevalence of Clostridium perfringens alpha toxin in processed and unprocessed fish. International Journal of Microbiological Research, 3(3), 195-199.

FAO. Food and Agriculture Organization of the United Nations (2009). Guide to good farming practices for animal production food safety. Roma.

FAO. Food and Agriculture Organization of the United Nations (2017). Resistencia a los antimicrobianos: Lo que necesitas saber. Datos básicos, desafíos y perspectivas sobre esta amenaza global.

FAO. Food and Agriculture Organization of the United Nations / Organización de las Naciones Unidas para la Alimentación y la Agricultura (2016). El estado mundial de la pesca y la acuicultura 2016. Contribución a la seguridad alimentaria y la nutrición para todos. Roma.

FAO. Food and Agriculture Organization of the United Nations. International Food Standards. Codex Alimentarius (2018). Antimicrobial Resistance.

FAO. Food and Agriculture Organization of the United Nations/Organización de las Naciones Unidas para la Agricultura y la Alimentación (1998). FAO Documento tecnico de pesca 348. H. H. Huss. Laboratorio Tecnológico. Ministerio de Pesca. Dinamarca.

Feng, G., Churey, J. J., \& Worobo, R. W. (2010). Thermoaciduric Clostridium pasteurianum spoilage of shelf-stable apple juice. Joumal of Food Protection, 73(10), 1886-1890.

García, S., \& Heredia, N. (2009). Clostridium perfringens: A dynamic foodborne pathogen. Food and Bioprocess Technology, 4(4), 624-630.

García-Sánchez, J. E., García-Sánchez, E., \& García-Moro, M. (2016). El microbiologo clinico ante los cambios taxonomicos en el genero Clostridium. Revista Espanola De Quimioterapia, 29(5), 239-243.

Gestal, M. C., Villacís, J. E., Alulema, M. J., \& Chico, P. (2014). De la granja a la mesa. Implicaciones del uso de antibióticos en la crianza de animales para la resistencia microbiana y la salud. Revista Cubana de Alimentación y Nutrición, 24(1), 11.

Gharaibeh, S., Al Rifai, R., \& Al-Majali, A. (2010). Molecular typing and antimicrobial susceptibility of Clostridium perfringens from broiler chickens. Anaerobe, 16(6), 586-589.

Gómez, S., Zapata, L. A., Medina, D. P., González, S. M., Caicedo, J. A., \& Baos, R. A. (2015). Guía de buenas prácticas pesqueras, una herramienta parala ordenación pesquera en el Pacífico colombiano. Cali.

González Alemán, M. (2013). Antimicrobial resistance, a world threat. Revista Cubana de Pediatría, 85(4), 414-417.

Granier, S. A., Moubareck, C., Colaneri, C., Lemire, A., Roussel, S., Dao, T.-T., \& Brisabois, A. (2011). Antimicrobial resistance of Listeria monocytogenes isolates from food and the environment in France over a 10-year period. Applied and Environmental Microbiology, 77(8), 2788-2790.

ISO. International Standard Organization (2004). ISO 7937:2004 (E). Microbiology of food and animal feeding stuffs. Horizontal method for the enumeration of Clostridium perfringens - Colony-count technique. Third edition.

Kimura, B., Kuroda, S., Murakami, M., \& Fujii, T. (1996). Growth of Clostridium perfringens in fish fillets packaged with a controlled carbon dioxide atmosphere at abuse temperatures. Journal of Food Protection, 59(7), 704-710.

Lorenzo, T. D., \& Gálvez, M. C. (2015). Las buenas practicas de manipulacion de alimentos en el hospital. Revista Cubana de Alimentación y Nutrición, 25(1), 22.

Massoc, P. A. (2008). Enfermedades asociadas a los alimentos. Revista Chilena de Infectología, 25(5), 395-397.

Matches, J. R., Liston, J., \& Curran, D. (1974). Clostridium perfringens in the environment. Applied Microbiology, 28(4), 655-660.

McNamara, A. M., \& Lattuada, C. P. (1998). Examination of meat and poultry products for Clostridium perfringens. United States Department of Agriculture USDA / Food Safety and Inspection Service. FSIS. Microbiology laboratory guidebook. 3rd ed. Chapter 13.

Microbiology of food and animal feeding stuffs. Horizontal method for the enumeration of Clostridium perfringens. Colony count technique. (n. d.).
Morris, W. E., \& Fernández Miyakawa, M. E. (2009). Toxinas de Clostridium perfringens. Revista Argentina de Microbiologia, 41(4), 251-260.

NOM-130-SSA1-1995. Norma Oficial Mexicana. Bienes y servicios. Alimentos envasados en recipientes de cierre hermético y sometidos a tratamiento térmico. Disposiciones y especificaciones sanitarias. Estados Unidos Mexicanos.

NOM-131-SSA1-2012. Norma Oficial Mexicana Productos y Servicios. Fórmulas para lactantes, de continuación y para necesidades especiales de nutrición. Alimentos y bebidas no alcohólicas para lactantes y niños de corta edad. Disposiciones y especificaciones sanitarias y nutrimentales. Etiquetado y métodos de prueba. Estados Unidos Mexicanos.

NOM-242-SSA1-2009. Norma Oficial Mexicana Productos y servicios. Productos de la pesca frescos, refrigerados, congelados y procesados. Especificaciones sanitarias y métodos de prueba. Estados Unidos Mexicanos.

NOM-251-SSA1-2009. Norma Oficial Mexicana. Prácticas de higiene para el proceso de alimentos, bebidas o suplementos alimenticios. Estados Unidos Mexicanos.

Olea, A., Díaz, J., Fuentes, R., Vaquero, A., \& García, M. (2012). Vigilancia de brotes de enfermedades transmitidas por alimentos en Chile. Revista Chilena de Infectología, 29(5), 504-510.

OPS. Organización Panamericana de la Salud / Pan American Health Organization (2016). Peligros biológicos.

Padgett, D., Luque, M. T., Rivera, D. M., Galindo, C., Zepeda, L., \& Hernández, A. (2011). Resistencia antimicrobiana en bacterias aisladas en el Instituto Hondureño de Seguridad Social. Revista Medica Hondurena, 79(3), 117-121.

PAHO. Panamerican Health Organization. World Health Organization. Codex Alimentarius (2015). Control sanitario. Principios generales de Higiene de los Alimentos del Codex.

Palomino Camargo, C., \& González Muñoz, Y. (2014). Molecular techniques for detection and identification of pathogens in food: Advantages and limitations. Revista Peruana de Medicina Experimental y Salud Publica, 31(3), 535-546.

Pascual Anderson, M. D. R., \& Calderón y Pascual, V. (2000). Microbiología alimentaria. Metodología analítica para alimentos y bebidas. 2da ed. Diaz de Santos.

Perdomo, I., \& Meléndez, P. (2004). Determinación y aislamiento de Staphylococcus aureus y Clostridium perfringens enterotoxigénicos a partir de alimentos. Revista Colombiana de Ciencias Químico Farmacéuticas, 33(1), 59-69.

Puig Peña, Y., Espino Hernández, M., \& Leyva Castillo, V. (2011). Resistencia antimicrobiana en Salmonella y E. coli aisladas de alimentos: Revision de la literatura. Panorama Cuba y Salud, 6(1), 30-38.

Ramírez Villalobos, R., \& Ishihara, H. (2008). Manual de buenas prácticas de manejo y aseguramiento de la calidad de productos pesqueros. Centro de Desarrollo de la Pesca y la Acuicultura (CENDEPESCA). Ministerio de Agricultura y Ganadería de El Salvador.

Recommendation of the Commission of the European Union of December 19, 2003 regarding a coordinated program of official control of food products for the year 2004. Recomendación de la comisión de la union Europea de 19 de diciembre de 2003 relativa a un programa coordinado de control oficial de productos alimenticios para el año 2004 [notificada con el número C (2003) 4878].

Reglamento (CE) No 178/2002 del parlamento europeo y del consejo. de 28 de enero de 2002. Regulation (CE) No 178/2002 of the European Parliament and the Council.

Rhodehamel, E. J., \& Harmon, M. S. (2001). Clostridium perfringens. Bacteriological analytical manual. Chapter 16. U. S. Department of Health and Human Services. U. S. Food and Drug Administration.

Ríos-Tobón, S., Agudelo-Cadavid, R. M., \& Gutiérrez-Builes, L. A. (2017). Patógenos e indicadores microbiológicos de calidad del agua para consumo humano. Revista Facultad Nacional de Salud Pública, 35(2), 236-247.

Romero Cabello, R. (2007). Microbiología y parasitología humana: Bases etiológicas de las enfermedades infecciosas y parasitarias. 3ra ed. Editorial Medica Panamericana.

Santos García, \& Norma, H. (2011). Clostridium perfringens: A dynamic foodborne pathogen. Food and Bioprocess Technology, 4(4), 624-630.

Sheyin, A. N., \& Solomon, K. J. (2017). Endo microbial fauna of Tilapia spp. (Oreochromis niloticus) found in a Flowing Canal at Eden Garden and Park Utako, Abuja. Journal of Fisheries and Livestock Production, 5(1), 214.

Slavić, Đ., Boerlin, P., Fabri, M., Klotins, K. C., Zoethout, J. K., Weir, P. E., \& Bateman, D. (2011). Antimicrobial susceptibility of Clostridium perfringens isolates of bovine, chicken, porcine, and turkey origin from Ontario. Canadian Journal of Veterinary Research, 75(2), 89-97.

Sonali Rivera Corona, M., Granda, A. E., Felipe, L., \& Bonachea, H. (2012). Resistencia antimicrobiana en cepas de Salmonella enterica subsp. enterica aisladas en carnes de aves importadas. Revista de Salud Animal, 34(2), 120-126.

WHO. World Health Organization (2007). Manual sobre las cinco claves para la inocuidad de los alimentos.

WHO. World Health Organization (2018). Health topics. Foodborne diseases.

WHO. World Health Organization (2018a). Food Safety. Infographics: Estimates of the global burden of foodborne diseases. 